\title{
Variation of Proliferative Activity in Leukemic Cell Populations of Patients with Acute Leukemia *
}

\author{
E. F. Saunders, $†$ B. C. Lampkin, $\$$ and A. M. Mauer $\S$ \\ (From the Department of Pediatrics, University of Cincinnati, The Children's Hospital, and \\ The Children's Hospital Research Foundation, Cincinnati, Ohio)
}

\begin{abstract}
Summary. In 31 children with acute leukemia, the proliferative activity of the leukemic marrow cell population as measured by mitotic and labeling indexes varied widely from patient to patient and from one disease stage to another. Leukemic marrow had a small but statistically significant diurnal variation of proliferative activity. Changes in labeling indexes were directly related to changes in the proportion of large dividing blasts in the marrow. Generation times of dividing leukemic blast cells in 3 patients were similar at diagnosis and in relapse. Changes in proliferative activity of leukemic marrow can be explained by progressive accumulation of nondividing leukemic cells.
\end{abstract}

\section{Introduction}

A marked variation from patient to patient has been observed in the proliferative activity of human marrow leukemic cell populations as measured by the per cent of cells incorporating tritiated thymidine (labeling index) and by the mitotic index. A difference of labeling index between blood and bone marrow leukemic cell populations in the same patient has already been reported $(1,2)$. This difference is due to a decreased number of dividing leukemic cells in the blood.

The variation of proliferative activity found in the marrow cell compartments in acute leukemia has not been explained. The changes could in part be caused by diurnal variation of proliferative activity or alterations of generation times for the dividing cells. The leukemic marrow is composed of both dividing and nondividing elements

\footnotetext{
* Submitted for publication March 8, 1967; accepted
} April 28, 1967.

Supported by grants CA 04826 and FR 00123 from the U. S. Public Health Service.

Abstracted in J. clin. Invest. 1967, 46, 1113.

$\dagger$ Supported by The Leukemia Society, Inc.

Address requests for reprints to Dr. E. F. Saunders, The Children's Hospital, Cincinnati, Ohio 45229.

$¥$ Advanced Clinical Fellow of the American Cancer Society, Inc.

§ Recipient of a Research Career Development Award from the National Institutes of Health.
(3) ; therefore changes in the proportion of dividing cells could also account for the observed variation.

The following studies were done to document the variation of proliferative activity and to attempt to ascribe a cause for it. The results of the studies indicate that changes in the proportion of dividing cells are primarily responsible for the observed variation.

\section{Methods}

Thirty-one children with acute leukemia, ranging in age from 1 to 14 years, were studied. All studies were in accordance with standards for clinical research established at our institution. As determined by morphological criteria (4), 5 patients had acute myeloblastic leukemia (AML), and the rest had acute lymphoblastic leukemia (ALL). The patients studied at the time of diagnosis were untreated; those seen in relapse had had all therapy discontinued before study. In only 7 of the 43 studies were the bone marrows less than $90 \%$ replaced by leukemic blast cells. Labeling indexes were determined by both in vivo and in vitro techniques. The mitotic index was measured in 15 patients.

In vitro studies. The mitotic index was determined by a modification of the method reported by Japa (5). One $\mathrm{ml}$ of marrow aspirated into a siliconized syringe was placed on a watch glass and immediately covered with acetocarmine solution. After 10 minutes marrow particles were transferred to glass slides. A cover slip was applied and sealed with silicone grease. Cover slips were tapped gently to spread the cells. Nuclear ma- 
TABLE I

Status of subjects

\begin{tabular}{|c|c|c|c|c|c|c|c|c|}
\hline \multirow[b]{2}{*}{ Patient } & \multirow[b]{2}{*}{ Age } & \multirow[b]{2}{*}{ Sex } & \multirow[b]{2}{*}{ Diagnosis* } & \multirow[b]{2}{*}{ Stage of disease } & \multicolumn{3}{|c|}{ Peripheral blood } & \multirow{2}{*}{$\begin{array}{c}\text { Bone marrow } \\
\text { replacement } \\
\text { by leukemic } \\
\text { cells }\end{array}$} \\
\hline & & & & & $\begin{array}{l}\text { Hemo- } \\
\text { globin }\end{array}$ & $\begin{array}{c}\text { Leuko- } \\
\text { cytes }\end{array}$ & Blasts & \\
\hline \multicolumn{9}{|c|}{ A. Diurnal variation } \\
\hline $\begin{array}{l}1 \\
2 \\
3 \\
4 \\
5 \\
6\end{array}$ & $\begin{array}{r}8 \\
4 \\
3 \\
4 \\
9 \\
10\end{array}$ & $\begin{array}{l}M \\
F \\
F \\
M \\
F \\
M\end{array}$ & $\begin{array}{l}\text { ALL } \\
\text { ALL } \\
\text { ALL } \\
\text { ALL } \\
\text { ALL } \\
\text { AML }\end{array}$ & $\begin{array}{l}\text { Relapse } \\
\text { Relapse } \\
\text { At diagnosis } \\
\text { At diagnosis } \\
\text { At diagnosis } \\
\text { At diagnosis }\end{array}$ & $\begin{array}{r}12.6 \\
7.4 \\
7.3 \\
5.8 \\
4.4 \\
7.0\end{array}$ & $\begin{array}{r}4.1 \\
6.4 \\
23.5 \\
2.9 \\
123.0 \\
52.1\end{array}$ & $\begin{array}{r}3 \\
62 \\
93 \\
8 \\
96 \\
77\end{array}$ & $\begin{array}{l}98 \\
95 \\
97 \\
98 \\
94 \\
86\end{array}$ \\
\hline \multicolumn{9}{|c|}{ B. Generation time } \\
\hline $\begin{array}{l}1 \\
2 \\
3\end{array}$ & $\begin{array}{r}11 \\
6 \\
8\end{array}$ & $\begin{array}{l}M \\
F \\
F\end{array}$ & $\begin{array}{l}\text { AML } \\
\text { ALL } \\
\text { ALL }\end{array}$ & $\begin{array}{l}\text { At diagnosis } \\
\text { Relapse } \\
\text { Relapse }\end{array}$ & $\begin{array}{r}5.6 \\
12.3 \\
7.1\end{array}$ & $\begin{array}{r}473.5 \\
88.5 \\
2.1\end{array}$ & $\begin{array}{r}97 \\
93 \\
1\end{array}$ & $\begin{array}{l}98 \\
97 \\
90\end{array}$ \\
\hline
\end{tabular}

* $\mathrm{ALL}=$ acute lymphoblastic leukemia $; \mathrm{AML}=$ acute myeloblastic leukemia.

terial was stained well by this technique and mitotic figures were readily identifiable. One thousand nucleated cells from each of 10 cover slip preparations were counted and the mitotic index was expressed as number per 1,000 cells.

By redirecting the bone marrow needle at the same site, we obtained a second aspiration with a heparinized syringe for the labeling index. One to $2 \mathrm{ml}$ of marrow was incubated with gentle shaking for 50 minutes at $37^{\circ} \mathrm{C}$ with tritiated thymidine (SA $360 \mu \mathrm{c}$ per mmole) in a concentration of $1 \mu \mathrm{c}$ per ml. Buffy coat was then obtained by spinning the sample for 10 minutes in a Wintrobe tube. Radioautographs were prepared from cover slip smears with Kodak AR 10 stripping film. After 10 to 14 days' exposure the film was developed and the slides were stained with Wright's stain. One thousand blast cells from each of 5 cover slips were counted and the labeling index was expressed as per cent. The background grain count in acellular areas of equal size to cell nuclei varied from 2 to 4 grains. Due to the excess of label used, there was no difficulty distinguishing labeled from unlabeled cells.

To assess the validity of the in vitro labeling method, we compared in vivo and in vitro labeling indexes in 3 patients. A marrow sample was aspirated for an in vitro labeling index as described above. Then an iv injection of $200 \mu \mathrm{c}$ tritiated thymidine per $\mathrm{kg}$ body weight was given. One hour later a marrow sample was aspirated and the per cent of marrow cells labeled determined by the radioautographic technique after a 60 - to 90-day exposure period.

Diurnal variation. Six children with acute leukemia were studied. The pertinent information concerning these patients is given in Table IA. The patients were hospitalized and followed the routine activity of an open ward appropriate for the age group. All were free of infection. During the study period the clinical status of the patients did not change and neither medications nor blood transfusions were given.
Bone marrow samples were obtained from four separate pelvic sites at 6-hour intervals during a 24-hour period (6:00 a.m., noon, 6:00 p.m., and midnight). No premedication was given but sites were well infiltrated with local anesthetic. In vitro labeling and mitotic indexes were determined for each time period.

The resulting data were subjected to an analysis of variance to determine the probability that the observed variations in mitotic index and per cent of cells incorporating tritiated thymidine could have occurred by chance. A p value $<0.05$ was considered significant. The Student range test was applied at the $5 \%$ significance level to obtain the minimal significant change $(K)$ of the indexes $(6 a)$.

Dividing and nondividing leukemic cells. The dividing and nondividing leukemic cells may be identified by morphologic criteria (3). Dividing blast cells are large with fine nuclear chromatin and nondividing blast cells are small with coarse nuclear chromatin. Only the large dividing cells incorporate label during a 1-hour incubation with tritiated thymidine. The leukemic cells were arbitrarily designated as being large or small in 10 studies on 5 patients based on their relative size and according to the characteristics of nuclear chromatin. The significance of the changes in labeling indexes and proportions of large blast cells was determined by means of Student's $t$ test $(6 b)$.

TABLE II

Correlation of 1-hour in vivo and in vitro labeling of leukemic cells

\begin{tabular}{ccr}
\hline \hline Patient & In vivo & \multicolumn{1}{c}{ In vitro } \\
\hline & $\%$ & $\%$ \\
1 & $11.8 \pm 1.7 *$ & $12.6 \pm 1.9$ \\
2 & $4.4 \pm 1.0$ & $5.5 \pm 0.7$ \\
3 & $5.0 \pm 1.1$ & $4.1 \pm 0.9$ \\
\hline
\end{tabular}

$* \pm 1 \mathrm{SD}$ 


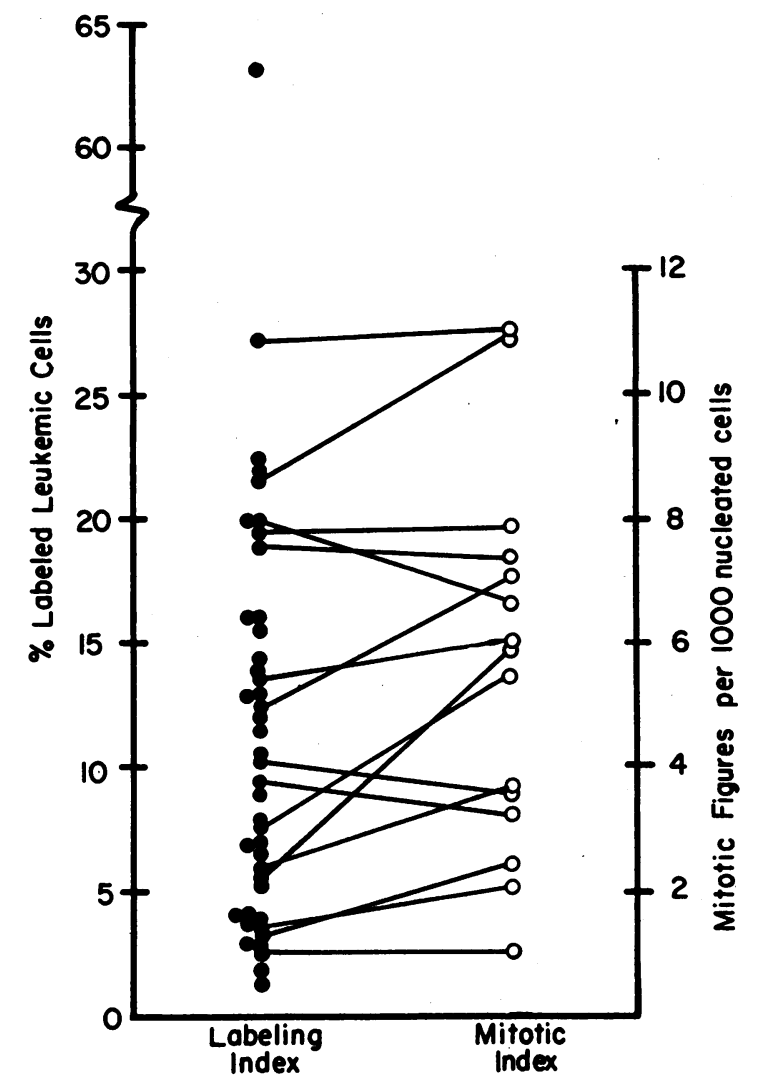

Fig. 1. LABELING AND Mitotic INDEXes OF MARRow LEUKEMIC CELLS: 43 STUdies IN 31 PATIENTS. Corresponding mitotic and labeling indexes are joined by a solid line.

In vivo studies. The generation time for dividing leukemic cells was determined in 3 patients by obtaining serial bone marrow samples after a single iv injection of tritiated thymidine (SA $360 \mu \mathrm{c}$ per mmole) in a dose of $200 \mu \mathrm{c}$ per $\mathrm{kg}$ body weight. Clinical data concerning these patients are given in Table IB. Radioautographs were prepared from the aspirated marrow samples and exposed for 60 to 90 days. The time course for the percentage of labeled mitotic figures was determined by counting 100 to 150 mitotic figures per marrow sample. Two values were obtained for each sample, one with cells having 3 grains or more and one with cells having 7 grains or more, in order to minimize the possible effect of label reutilization. The background grain count in acellular areas was 2 grains in a size similar to cell nuclei. In these studies the labeling index of the marrow was determined by the per cent of labeled cells in the 1 -hour sample.

\section{Results}

In an attempt to establish that an in vitro labeling index reflects proliferative activity in vivo, we studied 3 patients by the in vitro and in vivo methods simultaneously. As shown in Table II, the results did not vary significantly. The labeling indexes from 43 studies in 31 patients ranged from 1.8 to $63 \%$ (Figure 1). Corresponding mitotic indexes in 15 studies as shown in Figure 1 ranged from 1.0 to 11.1. There was good correlation ( $\mathrm{r} 0.80, \mathrm{p}<0.001)(6 c)$ between labeling and mitotic indexes as expressions of the proliferative activity of the leukemic cell populations.

Labeling indexes in 23 studies obtained at the time of diagnosis ranged from 1.8 to 15.5 with a mean value of $6.7 \%$ (Figure 2). As also shown in Figure 2, 20 labeling indexes obtained from patients in early relapse ranged from 6.0 to 63 with a mean value of $17.7 \%$. The difference in mean' values is significant $(\mathrm{p}<0.01)(6 b)$.

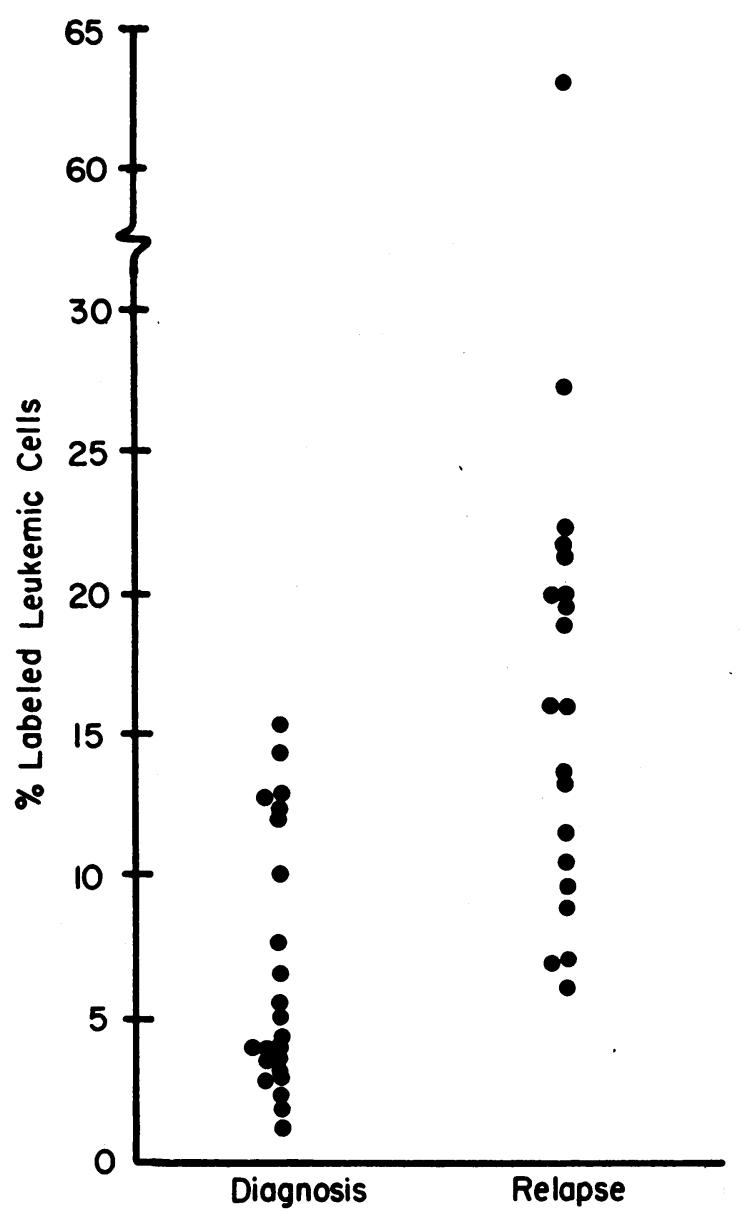

Fig. 2. Comparison OF LABELING OF MARROW LEUKEMIC CELlS AT TIME OF DIAGNOSIS AND RELAPSE: 43 STUdIES IN 31 PATIENTS. 
There was no difference in the degree of marrow replacement at the time of diagnosis and in relapse.

There was no correlation of labeling indexes with age or sex of the patient, type of leukemia, duration of survival from diagnosis, degree of marrow replacement with leukemic cells, or blood leukemic blast cell concentration. However, in the 9 patients with labeling indexes greater than $6 \%$ at the time of diagnosis, the duration of symptoms was less than 2 weeks. Conversely, patients with symptoms more than 2 weeks in duration at time of diagnosis had labeling indexes less than $6 \%$. Beyond this observation, no direct statistical correlation between labeling indexes and duration of symptoms could be developed ( $6 c)$.

Ten patients who were studied at the time of diagnosis were restudied in one or more subsequent relapses. The changes in labeling indexes are shown in Figure 3. In 8 patients a significant increase in labeling from diagnosis to the first relapse was found $(p<0.001)$. One patient having no change in labeling at the first relapse had a marked increase at the time of a second relapse $(\mathrm{p}<0.001)$. In one patient a decrease in labeling was found at relapse $(p<0.01)$ and in another a decrease from first to second relapse was observed $(p<0.001)$.

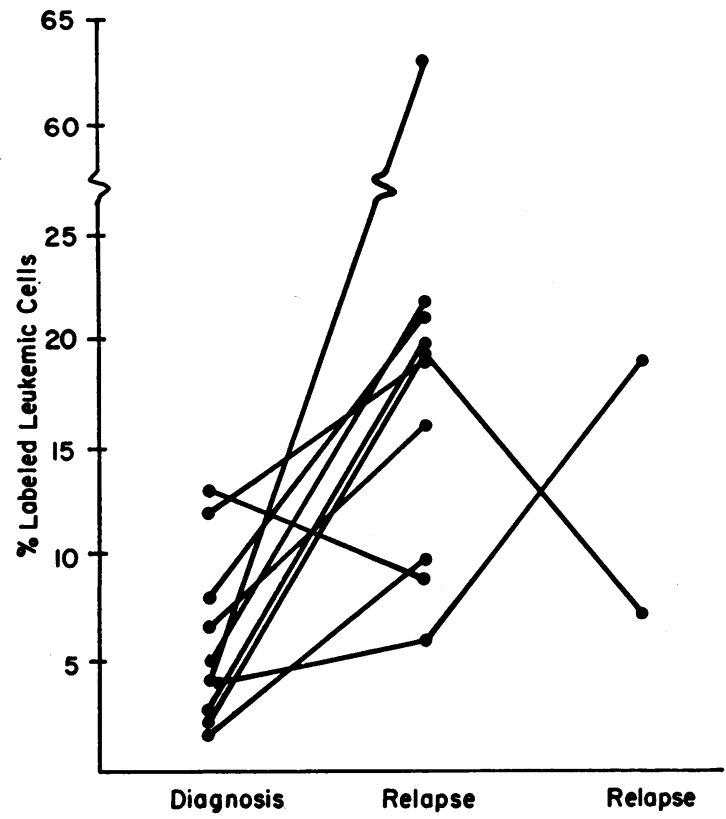

Fig. 3. Changes in labeling of marrow leukemic CELLS AT TIME OF DIAGNOSIS AND SUBSEQUENT RELAPSES.

To follow changes in labeling during a single relapse, we obtained labeling indexes a week apart in one patient who was receiving no therapy. The first index was $9.8 \pm 0.7 \%$ and the second $9.4 \pm$

TABLE III

Diurnal variation of mitotic indexes: mean number of mitotic figures per 1,000 nucleated cells

\begin{tabular}{|c|c|c|c|c|c|c|}
\hline Patient & 6:00 a.m. & Noon & 6:00 p.m. & Midnight & p value* & $\mathrm{K}$ value* \\
\hline $\begin{array}{l}1 \\
2 \\
3 \\
4 \\
5 \\
6\end{array}$ & $\begin{array}{c}10.1 \pm 1.0 \dagger \\
4.6 \pm 2.1 \\
3.6 \pm 1.8 \\
4.9 \pm 1.6 \\
1.2 \pm 0.7 \\
2.4 \pm 1.3\end{array}$ & $\begin{array}{l}9.9 \pm 2.6 \\
5.9 \pm 2.2 \\
5.6 \pm 1.9 \\
4.4 \pm 2.0 \\
0.8 \pm 0.8 \\
3.2 \pm 1.6\end{array}$ & $\begin{array}{r}11.4 \pm 1.9 \\
7.0 \pm 1.4 \\
4.9 \pm 1.7 \\
6.1 \pm 3.0 \\
1.2 \pm 0.8 \\
1.6 \pm 1.5\end{array}$ & $\begin{array}{r}13.1 \pm 3.4 \\
6.7 \pm 1.9 \\
7.8 \pm 1.7 \\
8.1 \pm 2.2 \\
0.8 \pm 1.3 \\
1.1 \pm 0.7\end{array}$ & $\begin{array}{l}<0.05 \\
<0.05 \\
<0.001 \\
<0.01 \\
\text { NS } \\
<0.01\end{array}$ & $\begin{array}{l}2.9 \\
2.3 \\
2.1 \\
2.7 \\
1.8 \\
1.5\end{array}$ \\
\hline
\end{tabular}

* See text.

$\dagger \pm 1$ SD.

TABLE IV

Diurnal variation of labeling indexes: mean per cent of leukemic blast cells incorporating tritiated thymidine

\begin{tabular}{|c|c|c|c|c|c|c|}
\hline Patient & $6: 00$ a.m. & Noon & 6:00 p.m. & Midnight & p value* & $\mathrm{K}$ value* \\
\hline $\begin{array}{l}1 \\
2 \\
3 \\
4 \\
5 \\
6\end{array}$ & $\begin{array}{c}23.2 \pm 1.4 \dagger \\
12.3 \pm 1.1 \\
8.3 \pm 1.5 \\
5.3 \pm 0.6 \\
2.1 \pm 0.3 \\
3.3 \pm 0.7\end{array}$ & $\begin{array}{r}30.1 \pm 4.3 \\
13.4 \pm 1.6 \\
8.3 \pm 0.8 \\
6.3 \pm 0.8 \\
2.0 \pm 0.4 \\
4.2 \pm 0.5\end{array}$ & $\begin{array}{r}27.3 \pm 2.7 \\
13.4 \pm 2.2 \\
6.5 \pm 1.6 \\
5.6 \pm 0.9 \\
3.3 \pm 0.8 \\
4.2 \pm 0.7\end{array}$ & $\begin{array}{r}28.4 \pm 1.5 \\
13.9 \pm 3.1 \\
7.5 \pm 1.4 \\
4.7 \pm 0.7 \\
2.4 \pm 0.9 \\
3.0 \pm 0.8\end{array}$ & $\begin{array}{l}<0.01 \\
\text { NS } \\
\text { NS } \\
<0.05 \\
<0.05 \\
<0.05\end{array}$ & $\begin{array}{l}4.9 \\
4.1 \\
2.4 \\
1.4 \\
1.2 \\
1.2\end{array}$ \\
\hline
\end{tabular}

* See text.

$\dagger \pm 1 \mathrm{SD}$. 
TABLE V

Changes in labeling index and proportion of large blasts with stage of disease

\begin{tabular}{clccc}
\hline \hline \multirow{2}{*}{ Patient } & Stage of disease & Marrow labeling index & Proportion of large blasts & $\begin{array}{c}\text { Labeling of } \\
\text { large blasts }\end{array}$ \\
\hline \multirow{2}{*}{1} & Diagnosis & \multicolumn{1}{c}{$\%$} & $\%$ & $\%$ \\
& Relapse & $21.8 \pm 5.3^{*}$ & $10.2 \pm 1.8$ & 50 \\
2 & Diagnosis & $6.7 \pm 1.4$ & $52.4 \pm 12.6$ & 41 \\
& Relapse & $16.1 \pm 1.8$ & $16.6 \pm 1.6$ & 40 \\
3 & Diagnosis & $4.5 \pm 1.3$ & $9.9 \pm 1.6$ & 48 \\
& Relapse & $21.3 \pm 4.4$ & $42.2 \pm 2.2$ & 45 \\
4 & Diagnosis & $2.0 \pm 0.5$ & $5.9 \pm 0.5$ & 50 \\
& First relapse & $20.0 \pm 1.9$ & $40.4 \pm 3.3$ & 34 \\
& Second relapse & $8.1 \pm 1.4$ & $19.5 \pm 1.8$ & 42 \\
\hline
\end{tabular}

$* 1 \mathrm{SD}$

$1.1 \%$. These values are not significantly different.

Diurnal variation. A statistically significant diurnal variation of mitotic indexes was found in 5 of the 6 patients studied (Table III). In 4 of the patients (no. 1, 2, 3, 4) the mitotic index was greatest at $6: 00$ p.m. or midnight as found in normal subjects (7). In Patient 6 the greatest value was at noon. There was no significant variation in Patient 5, whose marrow contained very few mitotic figures.

A small, although significant, variation in labeling indexes was found in 4 of the 6 patients ( $\mathrm{Ta}$ ble IV). In Patients 4 and 6 , the labeling index

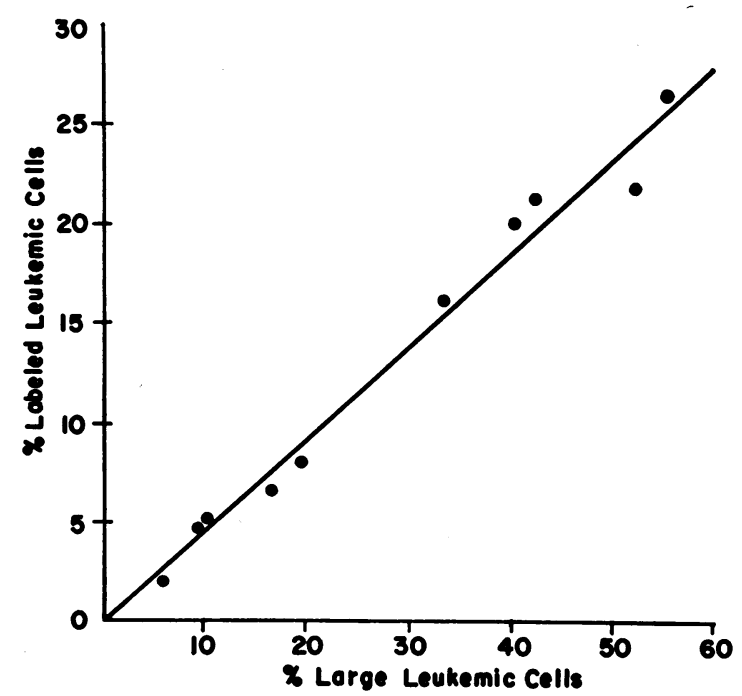

Fig. 4. CoRrelation OF LABELING INDEX AND PROPORTION OF LARGE LEUKEMIC CELLS: 10 STUDIES IN 5 PATIENTS. was least at midnight and in Patients 1 and 5 least at 6:00 a.m. and noon, respectively. No variation was found in Patients 2 and 3.

In the patient with no variation of mitotic index a significant variation of thymidine uptake was found, and in the 2 patients having no variation of thymidine uptake a significant variation in mitotic index was found. All patients, therefore, had significant variation in one or both of their measurements of proliferative activity.

Changes in proportion of dividing cells. In 4 of the patients having multiple studies it was possible to follow changes in the proportion of dividing leukemic cells from diagnosis to subsequent relapses. As shown in Table $\mathrm{V}$, in each patient an increase or decrease in the labeling index of the marrow leukemic cell population was associated with a corresponding increase or decrease in the proportion of large dividing cells. Labeling of the large cells varied from 34 to $50 \%$. The strong correlation of labeling indexes with proportion of dividing cells is shown in Figure 4. The coefficient 'of correlation of 0.98 is highly significant $(\mathrm{p}<0.001)(6 c)$.

Generation time of dividing leukemic cells. The time courses of appearance of labeled mitotic figures were similar in all 3 patients (Figure 5). There were no labeled mitotic figures in the 1-hour samples. After labeled cells had completed DNA synthesis and passed through the postsynthesis rest phase, labeled mitotic figures appeared, increasing to 80 to $90 \%$ by 10 hours. As the last cells of the labeled cohorts completed mitosis, unlabeled cells entered mitosis, and the per cent of labeled mitotic 


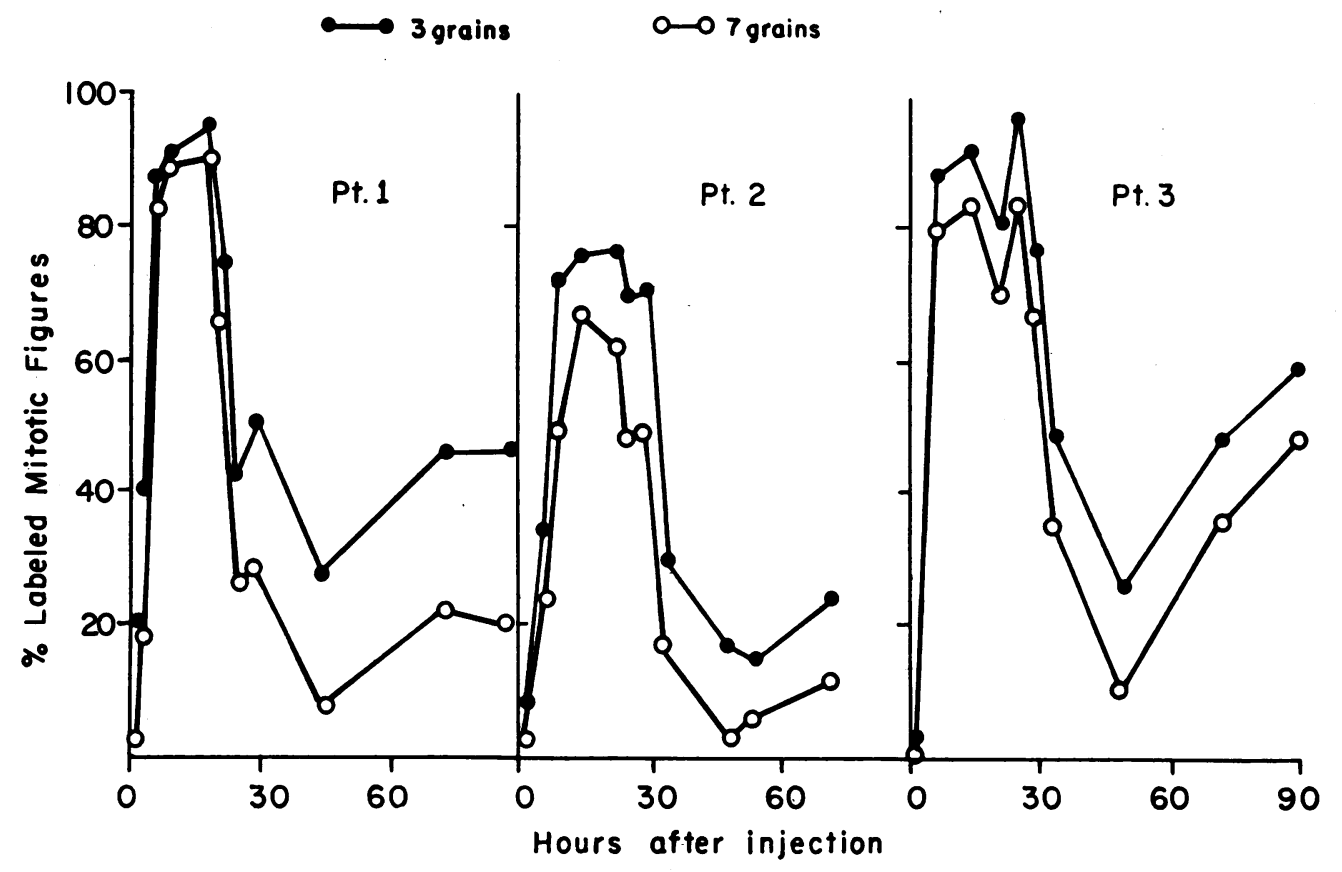

Fig. 5. Appearance of LAbEled mitotic figures after a SINGLe injection of tritiated th ymidine.

figures decreased at 30 to 40 hours. From the data is indicated a DNA synthesis period of about 20 hours. As the labeled cells entered a second mitosis an increase in per cent of labeled mitotic figures appeared at 50 to 70 hours, indicating a minimal generation time of approximately 60 hours.

\section{Discussion}

The use of tritiated thymidine and its evaluation as a cell label in vivo $(8,9)$ and in vitro $(10)$ have been previously discussed. The observed wide range of labeling indexes in marrow leukemic cells cannot be attributed to inability of some leukemic cells to incorporate label or to a heterogeneous distribution of label throughout the marrow (3). Because of the extensive marrow replacement by leukemic cells, variations in mitotic indexes could not be caused by presence of normal cell elements. The similarity of in vivo and in vitro labeling indexes found on simultaneous study in 3 patients indicates that both methods are valid reflections of proliferative activity. Dilution of marrow samples with leukemic cells from blood was not considered significant because there was no correlation of labeling index to blood leukemic blast concentration and also labeling indexes obtained from multiple simultaneous marrow aspirations did not differ significantly (3). Thus, wide variations are indicated from the data in the proliferative activity of marrow leukemic cell populations from patient to patient and in the same patient from one stage of the disease to another.

The presence of a diurnal variation of proliferative activity could affect interpretation of kinetic data. Myeloid elements of normal human marrow have a diurnal variation of proliferation as shown by mitotic and labeling indexes (7). A diurnal variation of thymidine uptake was not present in leukemic cells from blood (11), which, however, is generally not a proliferative compartment in acute leukemia $(1,2)$. Some experimental malignant tumors in animals maintain cyclic proliferative activity $(12,13)$. All 6 patients studied for diurnal variation of proliferative activity had a statistically significant diurnal variation in one or both measures. However, the magnitude of variation was insufficient to explain the wide range of proliferative activity found in these 31 patients. As some antileukemic drugs affect DNA synthesis, the presence of a diurnal variation of the proportion of leukemic cells in DNA synthesis could influence the time of maximal therapeutic effectiveness as demonstrated for some animal tumors 
(13). From the data on the small number of patients studied, no such consistently optimal time for daily therapy in human leukemia was found. It is of interest that in 4 patients studied, a diurnal variation of mitotic indexes like the normal pattern (7) was found, suggesting that the cells are responsive to some of the usual mechanisms controlling cell division.

The use of tritiated thymidine in vivo to determine generation times of leukemic cells presents many problems $(8,9)$. Patients may be submitted to a limited number of marrow aspirations. The resulting data may be difficult to interpret because of the loss of some labeled cells into background after division and label reutilization $(14,15)$. Only a minimal generation time can be obtained from the time course for labeled mitotic figures. It is reasonable that a range of generation times for dividing leukemic cells may exist in the same patient. The failure of the per cent of labeled mitotic figures to decrease to zero after the first wave of mitoses and the incomplete development of the second wave of labeled mitoses would support this hypothesis. Furthermore, heavily labeled mitotic figures indicative of first or second generation cells have been found as late as 210 hours after label injection (16). Thus, some leukemic cells may have a prolonged rest phase after the initial mitosis, appearing as heavily labeled mitotic figures 200 hours later. In spite of the above limitation, it appears that the minimal generation time for dividing leukemic blast cells was similar at diagnosis and in relapse in the 3 patients studied.

The relationship between blast size and thymidine uptake has been noted previously $(3,17,18)$. A strong positive correlation was found between the labeling index of the marrow cell population and the proportion of large, dividing blast cells. Therefore it is most reasonable to explain the observed variation in proliferative activity of marrow leukemic cell populations by changes in the proportion of dividing cells within those populations.

The proliferative activity of leukemic marrow was greater in relapse than at time of diagnosis. The patients in relapse were studied early in relapse, whereas patients seen for the first time at diagnosis may have been studied comparatively late in the development of their disease. It is of interest in this regard that patients with high la. beling-indexes at the time of diagnosis had relatively short duration of symptoms. Ehrlich ascites tumor cells in mice have a progressive decrease in labeling and mitotic indexes after implantation due to an accumulation of nondividing cells (19). The presence of nondividing blast cells in human leukemia has been demonstrated by several investigators $(2,3,17)$. The changes found in the proliferative activity of human leukemic marrow cell populations may also be due to an accumulation with time of nondividing cells. So far the available kinetic studies do not distinguish the nondividing cell from a cell having a very prolonged interphase.

If this concept is correct, then the labeling index of leukemic marrow cells should decrease as the patient is followed in relapse without therapy. In one patient so studied, a decrease in marrow cell labeling could not be demonstrated over a 1week period. However, the patient may have been studied too late in the period of "tumor maturation," or 1 week may have been an inadequate period of time to produce a significant change in proliferative activity.

\section{Acknowledgments}

We are grateful to Virginia Fisher, Jill Trefz, Aldora Loe, and Ruth Wright for technical assistance, and to Betty Powell for typing the manuscript.

\section{References}

1. Mauer, A. M., and V. Fisher. Comparison of the proliferative capacity of acute leukaemia cells in bone marrow and blood. Nature (Lond.) 1962, 193, 1085.

2. Killmann, S.-A. Proliferative activity of blast cells in leukemia and myelofibrosis. Morphological differences between proliferating and non-proliferating blast cells. Acta med. scand. 1965, 178, 263.

3. Mauer, A. M., and V. Fisher. Characteristics of cell proliferation in four patients with untreated acute leukemia. Blood 1966, 28, 428.

4. Boggs, D. R., M. M. Wintrobe, and G. E. Cartwright. The acute leukemias. Analysis of 322 cases and review of the literature. Medicine (Baltimore) $1962,41,163$.

5. Japa, J. A study of the mitotic activity of normal human bone marrow. Brit. J. exp. Path. 1942, 23, 272.

6. Goldstein, A. Biostatistics: An Introductory Text. New York, MacMillan, 1964, a) pp. 63-71, b) pp. $51-55, c)$ pp. $144-46$. 
7. Mauer, A. M. Diurnal variation of proliferative activity in the human bone marrow. Blood 1965, 26, 1.

8. Cronkite, E. P., V. P. Bond, T. M. Fliedner, and J. R. Rubini. The use of tritiated thymidine in the study of DNA synthesis and cell turnover in hemopoietic tissues. Lab. Invest. 1959, 8, 263.

9. Killmann, S. A., E. P. Cronkite, T. M. Fliedner, and V. P. Bond. Cell proliferation in multiple myeloma studied with tritiated thymidine in vivo. Lab. Invest. 1962, 11, 845.

10. Rubini, J. R., S. Keller, and E. P. Cronkite. In vitro DNA labeling of bone marrow and leukemic blood leukocytes with tritiated thymidine. 1. Physical and chemical factors which affect autoradiographic cell labeling. J. Lab. clin. Med. 1965, 66, 483.

11. Roll, K., and S. A. Killmann. Lack of diurnal variation in tritiated thymidine labelling index of human leukaemic blast cells. Nature (Lond.) 1965, 205, 1235.

12. Voutilainen, A. Über die 24-Stunden-rhythmik der Mitosenfrequenz in malignen Tumoren. Acta path. microbiol. scand. 1953 (suppl. 99).

13. Badran, A. F., and J. M. Echave Llanos. Persistence of mitotic circadian rhythm of a transplantable mammary carcinoma after 35 generations : its bear- ing on the success of treatment with endoxan. J. nat. Cancer Inst. 1965, 35, 285.

14. Baserga, R., and W. E. Kisieleski. Comparative study of the kinetics of cellular proliferation of normal and tumerous tissues with the use of tritiated thymidine. 1. Dilution of the label and migration of labeled cells. J. nat. Cancer Inst. 1962, 28, 331.

15. Maruyama, $Y$. Re-utilization of thymidine during death of a cell. Nature (Lond.) 1964, 201, 93.

16. Mauer, A. M., B. C. Lampkin, and E. F. Saunders. Kinetics of leukaemia cells. Proceedings of the XIth Congress of the International Society of Haematology. Plenary Sessions, Sydney, 1966, Sydney, Victor C. N. Blight, 1966, p. 42.

17. Gavosto, F., A. Pileri, C. Bachi, and L. Pegoràro. Proliferation and maturation defect in acute leukaemia cells. Nature (Lond.) 1964, 203, 92.

18. Killmann, S. A., E. P. Cronkite, V. P. Bond, and T. M. Fliedner. Proliferation of human leukemic cells studied with tritiated thymidine in vivo. Proceedings of the VIIIth Congress of the European Society of Hematology, Vienna, 1961. Basel, S. Karger, 1962.

19. Baserga, R. Mitotic cycle of ascites tumor cells. Arch. Path. 1963, 75, 156. 